\title{
Preface to BIT 56:4
}

\author{
Lars Eldén ${ }^{1}$
}

Published online: 25 November 2016

(C) Springer Science+Business Media Dordrecht 2016

I am sad to announce that two of our associate editors have passed away during 2016.

\section{Timo Eirola, 1951-2016}

Timo's research areas were numerical dynamical systems, methods for differential equations, numerical linear algebra, and smoothness of wavelets. He was an associate editor since 1999. An obituary is published in NA Digest: http://www.netlib.org/ na-digest-html/16/v16n21.html.

\section{Hans Petter Langtangen, 1962-2016}

Hans Petter did research on the efficient solution of differential equations, and produced scientific software of extremely high quality. He was an associate editor since 2007. An obituary is published at http://hpl-memorial.simula.no/.

We are deeply grateful for the service of Timo and Hans Petter to the numerical community, and we miss two good friends.

\section{New Associate Editors}

Three new associate editors have been appointed:

\footnotetext{
$\bowtie$ Lars Eldén

lars.elden@liu.se

1 Linköping University, Linköping, Sweden
} 
- Marko Huhtanen, Oulu University.

Matrix and operator theory, iterative methods, numerical algorithms and applications in mathematical physics.

- Elisabeth Larsson, Uppsala University.

Radial basis function approximation, parallel programming, computational finance, computational wave propagation, tensor notation for grid operators.

- Antonella Zanna, University of Bergen.

Numerical analysis/geometric integration, image processing.

We welcome them to the work in the editorial board.

Anna-Karin Tornberg has asked to leave the assignment as associate editor. We thank her for her good work in the past!

Lars Eldén, editor-in-chief 